\title{
Creativity in Adulthood
}

Maciej Karwowski ${ }^{1}$ and Ewa Wiśniewska ${ }^{2}$

${ }^{1}$ University of Wrocław, ${ }^{2}$ The Maria Grzegorzewska University

This is the accepted version of a chapter that will appear in: J. D. Hoffman, S. W. Russ, and J. C. Kaufman (Eds.), The Cambridge Handbook of Lifespan Development of Creativity, Cambridge University Press

\section{Authors' Note and Acknowledgement}

Ewa Wiśniewska, Department of Educational Sciences, Creative Education Lab, The Maria Grzegorzewska University, Szczesliwicka 40, 02-353 Warsaw, Poland. Maciej Karwowski, Institute of Psychology, University of Wroclaw, Dawida 1, 50-527 Wrocław, Poland.

Maciej Karwowski was supported by a grant (\#UMO-2016/22/E/HS6/00118) from National Science Centre, Poland.

Please address correspondence concerning this chapter to Maciej Karwowski (Maciej.Karwowski@uwr.edu.pl) 


\begin{abstract}
Adulthood holds a special promise for creativity. Not only is this developmental period the longest, but also the most advanced in terms of maturity of mental and biological structures people achieve. Therefore, adulthood quite naturally forms an arena for creative activities and achievements. However, creativity in adulthood does not only (or even not mainly) refer to test-measured creative potential; rather, it denotes expertise-based, mature, and in some rare cases, eminent creativity. What are the milestones of creative development in adulthood? Why is it that so many people do not reach the level of mature creativity? What makes adults realize, or not, their creative potential, and invest their time and effort to develop it? We discuss these questions and show some new avenues for future research.
\end{abstract}

Keywords: adulthood; creative potential; creative achievement; development 


\section{Creativity in Adulthood}

When it comes to creativity, adulthood is a unique and somewhat paradoxical period. It is unique, as it is only in adulthood when people gain sufficient experience and knowledge to accomplish something creative to the extent that will be recognized by professional fields (Csikszentmihalyi, 1988). Apart from differences between domains, i.e. earlier achievements in more rather than less structured fields (Simonton, 2009), outstanding discoveries in adolescence, not to mention childhood, are extremely scarce. Adulthood, however, is also ambiguous when it comes to creativity. Most studies published in creativity literature focus on children and adolescents or university students as 'emerging adults' (see Arnett, 2000). These investigations usually operationalize creativity either as creative potential (often measured by divergent thinking tests, e.g. Runco \& Acar, 2012; but see also Silvia et al., 2016) or as creative activity, including pretend play (Hoffmann \& Russ, 2012, 2016).

Creativity scholars rarely examine achievements of children or adolescents, likely guided by the assumption that it makes very little sense to talk about creative accomplishments before adulthood (Feldman, 1999). Indeed, it is in adulthood when creative potential crystallizes and (at least sometimes) transforms into achievement.

What kind of creativity is being analyzed when adulthood is considered? Are there any specificities of this developmental period for creativity? Should we focus on creative thinking alone or perhaps our interests should focus on measurable and recognizable achievement? What about being creative in new personal and social roles that arise in adulthood? These questions direct our interests in this chapter.

We organize this chapter around three main conceptual problems. First, we provide a brief overview of general perspectives to show differences between developmental change models - linear, stage, and cyclical models — and discuss the role of developmental and creative crises. Although we focus on adulthood, in this part we situate emerging adulthood 
in the context of earlier developmental phases with a special focus on the transition between adolescence and emerging adulthood. Then, we take a closer look at the question of what kind of creativity we are talking about in adulthood. Is creativity understood as a result of some sort of a test (be it divergent thinking, insight, etc.) or perhaps as an activity conducted in one's kitchen or at the office? Being a partner, parent, employee? Finally, we discuss the role of creative self-beliefs to speculate why many adults tend not to choose the path that might eventually lead to creative achievement.

\section{The Age of Maturity}

So, when does adulthood actually begin? Usually, the period between early twenties and late thirties is defined as early adulthood, while middle adulthood lasts from approximately 40 to about 60 years of age (see e.g. Srivastava et al., 2003). Then, late adulthood begins during the sixties or seventies and continues until death. In the psychological sense, adulthood is about becoming aware of one's needs, expressing one's will, and taking responsibility for the way these needs are met. Consequently, adulthood is inherently related to social obligations primarily linked to professional and family life. The two classic categorizations of adulthood were proposed by Erikson (1968) and Levinson (1986). Erikson distinguished between early (18/20-30/35 years old), middle (30/35-60/65), and late adulthood (after 60/65 years old). Levinson proposed that early adulthood falls between 17 and 45 years of age, middle adulthood between mid-forties and mid-sixties, and late adulthood after that period. In each of these periods, people encounter specific developmental tensions and challenges, which they have to deal with to thrive. Since creativity in late development is discussed in detail elsewhere (see Kahana \& Kahana, this volume), here we focus on earlier periods. In interpreting changes in creativity, we apply the theoretical perspective proposed by Arnett (2000), who considers the period of 18-25 years of age as one of emerging adulthood: a particular time between adolescence and adulthood. 
There are also more recent arguments to consider the period between the ages of 30 and 45 as established adulthood (Mehta et al., 2020): a stage of special importance not only for the three vital developmental challenges of adulthood: work, relationships, and parenthood, but also for creativity (see Mehta et al., 2020).

\section{Creativity in Developmental Perspective}

Change is central to creativity (Beghetto, 2016). It is also the most obvious indicator of development. Understanding developmental change and trajectories plays a crucial role in formulating and testing theories of development and creativity. As Sawyer (2003) recognizes, the key link between developmental theories and creativity theories is the focus on "process." Classic constructivist theories, including those of Piaget (1928/1959) or Vygotsky (1980), attributed the essence of development to a process in which people construct and enrich their knowledge thanks to continuous interaction with the environment and confrontation with themselves. Talking about "process," despite its postulated dynamism (Beghetto \& Corazza, 2019), often directs attention to its different "endpoints;" in the case of creativity, those are usually products; in the case of development - its subsequent stages (Sawyer, 2003). Indeed, many theories of creativity emphasize its developmental character, with a transition between certain levels or stages (see Beghetto \& Kaufman, 2007; Kaufman \& Beghetto, 2009;

Richards, 2007; Runco, 2014) and specific achievements at each stage.

The central premise of the phase or stage models (e.g., Freud, 1915/1958; Kohlberg, 1987; Piaget, 1928/1959; Vygotsky, 2004) is that an individual goes through different stages of development, usually in the same order. Each step consists of a process of experience differentiation (a progression phase) and a process of ordering and integrating the newly acquired experience (plateau). For instance, inspired by Piaget's theory, Feldman's (1994) domain-specific model posits that an individual develops competences in a specific domain of creative activity in addition to universal increases in intellectual abilities. Development of 
an adult human is of constant character - from universality to uniqueness - but it is qualitatively differentiated on many levels of activity.

Cyclic-phase models are based on experience transformation processes: the new experiences change the quality of the previous ones, undergo transformations, and give them a new form. Cyclicality of the changes is a critical element of these models, with progression, plateau, regression, and crisis as its elements. The climax of change at any stage is the moment of crisis, which is the nucleus of the next cycle of development, the beginning of a qualitatively new process of change (e.g., Cohen, 2009; Dąbrowski, 1964; Erikson, 1968, 1982; Levinson, 1986). For example Cohen $(1989,2012)$ placed creativity on a continuum from childhood to adulthood, perceiving the essence of creative development in the transition to more mature ways of adaptation to reality. Importantly, Cohen does not equate changes in creativity with age alone, but rather with different mechanisms that are related to accumulated experiences. Several key elements are taken into account in her cyclical model of development, namely (1) purpose: from mastery of a given field to transformation of that field; (2) novelty: from subjective novelty for the individual to novelty for the world; (3) value: from personal value for the subject to objective value; (4) speed: from short-term to long-term activities; (5) structure: from creating structures to transforming them; and (6) adaptation as a result: from adapting to the world to changing the world. Consequently, creative behaviors might manifest themselves at seven levels of growing complexity and difficulty, from (1) learning something new, (2) making connections which are rare, (3) demonstrating talents, (4) developing heuristics, (5) producing information, (6) extending the field, to (7) transforming the field (Cohen, 1989; p. 170-177).

What is the shape of developmental change when it comes to creativity? According to the Peak and Decline Model, creativity increases in early adulthood until late 30s and then declines after 40 years of age. Yet changes aside, creativity is understood here as the same 
construct throughout life, with quantitative rather than qualitative changes in time (Levy \& Langer, 1999). In turn, the Life Span Developmental Model (see Bornstein \& Kennedy Shriver, this volume) perceives creativity as a phenomenon that holds different meanings at different stages of life. Therefore, it makes little sense to analyze changes in, say, divergent thinking. Instead, exploring how creativity is expressed at various stages of life becomes theoretically fruitful and relevant (Levy \& Langer, 1999).

\section{On the Crystallization of Potential}

A useful theoretical model allowing for a developmental analysis of creativity across lifespan is the one proposed by Nęcka (2001; Nęcka et al., 2006). Similarly to Kaufman and Beghetto's Four C model (2009), this approach recognizes four levels of creativity, yet with a slightly different focus. These levels are defined as fluid creativity, crystallized creativity, mature creativity, and eminent creativity.

Fluid and crystallized creativity, named by an analogy with the classic intelligence theory (Cattell, 1963), appear early and develop through childhood until early adulthood. Ideation is a key cognitive process on the level of fluid creativity. Ideas are either retrieved from memory or created (Miroshnik \& Shcherbakova, 2019) and combined into novel solutions (Silvia et al., 2017). Fluid creativity denotes a relatively universal potential, an opportunity, and a premise for the development of higher levels of creativity. It benefits not only from divergent thinking (Guilford, 1967; Runco \& Acar, 2012), but also from curiosity (Hardy et al., 2017; Schutte \& Malouff, 2019), novelty seeking (Gocłowska et al., 2019), intrinsic motivation and play (Amabile, 1996; Russ, 1993), as well as mood and positive emotions (Baas et al., 2008; Davis, 2009).

Fluid creativity stabilizes and transforms into crystallized creativity with time, mainly when an individual receives training within a particular domain and thus obtains a certain amount of domain-specific knowledge. Having necessary skills, seeing problems, building, 
and changing cognitive representations, using critical thinking - all these factors contribute to the development of crystallized creativity. Crystallized creativity is slightly right-skewed in the population, so low results are more typical than high results. As with everyday creativity (Richards, 1994/2017), however, crystallized creativity is within reach of most adults; this is a type of creative activity that responds to the problems of personal and professional life. Both fluid and crystallized creativity are driven by enjoyment (Benedek et al., 2019); engagement in creative activities tends to be associated with positive affect (Conner et al., 2018; Karwowski et al., 2017) and stifled by anger and stagnation (Conner \& Silvia, 2015; Silvia et al., 2014).

Mature creativity partially resembles Pro-c level from the Four C model (Kaufman \& Beghetto, 2009). Emerging (if at all) in established adulthood, mature creativity allows an individual to take up important goals and solve real problems, relevant in a particular domain, and create products that are socially recognized. The key at this stage is to choose questions worth answering, which becomes a strategic decision (Sternberg \& Lubart, 1995). Mature creativity requires rich and extensive procedural and declarative knowledge (Ericsson \& Charness, 1994). The right choice of a problem to solve naturally requires a solid understanding of the field, so mature creativity is for experts, not for novices. While it is widely acknowledged that becoming an "expert" takes about ten years of deliberate practice (Ericsson et al., 1993; Simon \& Chase, 1973), creativity seems to require many more than that (Hass \& Weisberg, 2015; Hayes, 1989; Kaufman \& Kaufman, 2007).

Eminent creativity stands at the top of creativity levels. It might be considered a very particular kind of mature creativity, a Big-C equivalent that results in products that fundamentally change the domain (Nęcka, 2001; Simonton, this volume). Eminent creativity is, by definition, rare. Thus, although virtually all eminent creators are adults, only a very few adults are eminent creators. In fact, most adults do not report any observable and recognized 
creative results of Pro-c or Big-C nature (Silvia et al., 2012), nor engage in creative activity (Karwowski \& Brzeski, 2017; von Stumm et al., 2011).

While there is some empirical evidence of developmental trends in divergent thinking or creative abilities in general (see the section Changes in the Level of Creative Ability) in non-eminent adults, it is not clear whether the same patterns apply to more professionalized creativity or even to eminent creators, when creative achievement, lifetime contributions, or productivity are considered. For example, a recent meta-analysis has demonstrated that older entrepreneurs outperformed younger ones in professional success, but the patterns were far from linear (Zhao et al., 2020). Also, among professional creators, the productivity curve first quite rapidly increases, achieves a single peak, and then slowly, yet gradually declines (Simonton, 1994). Several sources, both anecdotal and empirical, suggest that chronological age is less important than the age at the start of a career. Usually, however, productivity reaches a peak in late thirties or early forties, and then gradually decreases (Lehman, 1953; Simonton, 1994, 1997). Prodigies, late bloomers, persisters, polymaths, and field changers are examples of rare exceptions (Root-Bernstein, 1999). As Simonton (2012) argues, the decline in creativity at the end of middle adulthood might be less due to aging per se than to internal or external factors. The observed differences in productivity may indicate different strategies to maximize creativity at any age or any stage of working life (Root-Bernstein, 1999). Indeed, as Root-Bernstein and Root-Bernstein (2011, p. 52-53) proposed, there are different types or trajectories through a creative lifetime: (1) early specialization, single mature focus; (2) early breadth, mature focus; (3) early breadth, mature breadth; (4) early specialization, mature breadth; (5) early specialization, serial mature foci; (6) early breadth, serial mature foci. These types differ in the developmental patterns of creativity. Therefore, it is quite possible that there is no one-size-fits-all pattern when creativity development is 
considered; quite the opposite — creative achievement might and often do develop in different trajectories.

\section{Creative and Developmental Crises}

A crisis stimulates changes and forms an opportunity for internal transformation of experience. As the theory of positive disintegration (Dąbrowski, 1964; Tillier, 2018) posits, disintegration of personality is necessary to achieve maturity. Disintegration is, therefore, a positive process, and such a crisis might even be considered creative as it leads to selfcreation (see Kaufman, 2020). It allows individuals to overcome previous limitations and, above all, enables them to achieve maturity. Levinson (1986) proposed that midlife crisis transforms the way of thinking, feelings, relations with the environment, re-evaluation of plans for further life, and priorities. Among the four pairs of opposites, which a person is facing, Levinson explicitly mentions the relation and tension of creativity vs. destruction in this period (see also Dacey, 1989). Indeed, the individual, together with aggressive and destructive tendencies, gains energy to oppose obstacles and strength to implement creative solutions, innovations, and transformations.

Also, in the classic theory of Erikson (1982), the development of the ego and the ability to overcome crises is critical for achieving maturity. At each of the eight stages this theory denotes, people face specific crises and developmental tasks. Crises are normative and, therefore, must be resolved at a particular stage for an individual to reach a higher developmental stage. Discussing Erikson's theory from a perspective of creativity development, Dollinger et al. (2005) emphasize two phases: adolescence, when the formation of identity is crucial, and middle adulthood, when the pillar of vitality becomes generative. As Marcia (2002) added, identity achievement is the optimal way to move from late adolescence to mature life. Exploration and commitment are two processes that lead to the desired status of identity (Luyckx et al., 2008; Marcia, 2002). Exploration denotes 
experimenting, active searching, trying, testing oneself, and one's abilities, as well as relationships with other people. Although exploration as a way to identity development is typical for adolescence (see Barbot, this volume), recent theories emphasize its importance also during emerging adulthood (Arnett, 2000). Commitment denotes investing one's resources in a specific practical (e.g. work) or mental (e.g. worldview, ideology) area. Thanks to exploration and commitment, a person is able to answer the who am I? question. In that perspective, creativity is not only an activity that leads to new and meaningful products, but mainly allows for the "creation of oneself." Indeed, the process of identity formation makes it possible to find an appropriate role in the integration of all the previously performed ones, and such consolidated identity is instrumental for further creative activities (Helson \& Pals, 2000; Rothenberg, 1990). Apart from personal identity, occupational or professional roleidentity also plays a vital role for creativity in adulthood (see Petkus, 1996) and builds on interests from adolescence (Albert, 1990).

According to Erikson (1968), intimacy is the key developmental achievement in early adulthood. In this period, creative behavior might become a way to manage oneself, open up to others and the world, contribute to shaping one's lifestyle, and lead to personal and professional fulfillment. As a meta-analysis (Årseth et al., 2009) showed, there is a positive link between successfully achieved intimacy status and a person's identity.

Self-realization of one's potential is particularly intense in established adulthood. In Erikson's (1968) words, this is when the crisis of stagnation vs. generativity occurs. Generativity is understood here as productivity associated with transmission of values and traditions to younger generation (McAdams \& Logan, 2004). There is empirical evidence that on average, people in established adulthood show higher generative balance than emerging adults (Beaumont \& Pratt, 2011). 
Late adulthood is accompanied by the need for ego integrity (vs. despair) and perception of one's legacy, as illustrated by Horace's non omnis moriar (not all will die). The more an individual's life was filled with creative experiences, the higher the hope of leaving traces for future generations and, at the same time, the higher the chance of overcoming the crisis in the form of a state of despair, hopelessness, a sense of decline, and the end of life (Erikson, 1982).

\section{Changes in the Level of Creative Ability}

When adulthood emerges, higher mental functions are usually already wellsynchronized (Vygotsky, 2004), so adults are cognitively mature not only to use their creative abilities effectively, but also to self-regulate their processes (see, e.g. Ivcevic \& Nusbaum, 2017). While some early studies found a decline in divergent thinking in emerging and established adulthood compared to younger adults (Alpaugh \& Birren, 1977; Alpaugh et al., 1982; Guilford, 1967; McCrae et al., 1987; Reese et al., 2001), more recent investigations tend to show the lack of differences between the early and intermediate stages of adulthood (Adnan, Beaty, Lam, et al., 2019; Adnan, Beaty, Silvia, et al., 2019; Foos \& Boone, 2008; Jaquish, \& Ripple, 1984; Madore et al., 2016; Palmiero, 2015; Palmiero et al., 2014; RoskosEwoldsen et al., 2008). Divergent thinking develops intensively in late adolescence and emerging adulthood (Kleibeuker et al., 2013). This also applies to the more synthetic creative abilities as measured by the figural Test of Creative Thinking-Drawing Production (TCT-DP) (Urban, 2005); a large study observed an increase in results from adolescents to around 19 years of age, with a peak at 20 years of age and further stabilization at around age 21 (Gralewski et al., 2016).

Importantly, in emerging adulthood, creative abilities integrate with knowledge and experience (Wu et al., 2005) as well as cognitive control (Benedek et al., 2014). More experienced adults are able, especially in tasks requiring abstract thinking, to come up with 
more diverse and original responses than children or adolescents. This positive trend is also influenced by developing language proficiency, conceptual thinking, and communicative competence (Wu et al., 2005). Moreover, creative thinking is associated with more flexible coordination between analytical and associative information processing, which affects the quality of ideas (Martindale, 1999). This ability is related to the intensive development of prefrontal areas of the brain (Kerns, 2006; Kerns et al., 2004), not yet fully developed in adolescence (Runco, 2014).

Runco (1996) suggests that the experience of adults sometimes works against creative thinking by involving cognitively rigid, more automated reasoning. Yet, it is also possible that for adults — especially established adults — divergent thinking tasks are to a large extent meaningless and unable to raise sufficient motivation to engage in such a superficial activity as solving the test (Kilgour, 2006; Zeng et al., 2011). Indeed, there are likely more adequate forms of creativity for adults than solving tests. In what follows, we consider a number of such adult-specific forms of creativity.

\section{Adulthood-Specific Forms of Creativity}

\section{Adults' Creativity and Mating}

Late adolescence and emerging adulthood are periods of a growing importance of romantic relationships, mating, and intimacy. What is the role of creativity here? Evolutionary accounts provide a number of important theoretical and empirical insights.

Evolutionary psychologists consider creative potential as an indirect, yet critical indicator of fitness (e.g. Miller, 1999, 2000). Miller's Cultural Courtship Model (CCM) is likely the most far-reaching in positing that sexual selection primarily stands behind the development of creativity (Miller, 1999, 2000, 2008). Indeed, a number of studies show that creative potential is a desirable trait of a mate (Buss, 1989; Geher \& Kaufman, 2013; Li \& 
Kenrick, 2006; Rowatt et al., 2001), sometimes valued as highly as social status (Buss \& Barnes, 1986) or intelligence (Prokosch et al., 2009).

Even changes in creative productivity over the lifespan have been explained by mating processes. Indeed, many famous creators were most prolific in their early and middle adulthood, with longer peaks observed among singles (Kanazawa, 2000; Simonton, 1988, 1997) - a pattern consistent with CCM proposition that "cultural production should increase rapidly after puberty, peak at young adulthood when sexual competition is greatest, and gradually decline over adult life as parenting eclipses courtship" (Miller, 1999, p. 81).

In a large $(N=125)$, qualitative study of established creators' family relations, Lebuda and Csikszentmihalyi (2020), provided a typology of creators based on two criteria: their identity as creators and perception of family roles. It resulted in five categories. First, a supported creator is someone who perceives creativity as a kind of duty and at the same time holds quite a traditional perception of family roles. Consequently, a partner is expected to provide support and care about the family microsystem. The second type, solitary creator, is someone who is wholly devoted to creativity and therefore often decides to live and work alone. This type, however, defines family roles in a much more flexible way - as exchanging work and sharing duties. The third type is a professional creator. Professional creators are people who think about creativity as a profession; their perception of family duties is traditional. These are people who are creators at work and moms or dads at home - their creativity is usually limited to work-settings. The fourth category is after-hour creators, or people who see creativity as a craft they engage in. As their perception of the family role is traditional, they are often overloaded by tensions between family and creativity-related obligations. Finally, the fifth and last type is non-stop creators - people who are entirely devoted to creative work and define family-roles in a flexible way. These people often cooperate with their partners who also engage in creativity. 
What Lebuda and Csikszentmihalyi (2020) demonstrate are different ways of how the family relationships may build creative peoples' well-being, but also identify the kinds of tensions and threats for mental functioning and creative activity it provides. Contrary to a widespread belief, the authors show that professionally creative people are not lonely wolves and family plays a crucial role in their functioning. Except for solitary creators, all the remaining four types are deeply family bonded and driven by the relationships with their loved ones.

If creativity is found attractive, there are reasons to expect that more creative people should have more sexual partners than the less creative people. Indeed, the number and quality of creative works among professionals is positively related to the number of sexual partners (Clegg et al., 2011). What's more, creative and successful males are considered more sexually attractive than the less creative males (Clegg et al., 2008); they also report more sexual partners than the less creative ones (Beaussart et al., 2012; Lange \& Euler, 2014; Nettle, 2008). What is less obvious, however, is whether more creative people are also more reproductively successful. Evolutionary reasoning would suggest so, yet empirical evidence is lacking, partially because the majority of contemporary creativity studies is conducted in WEIRD (Western, Educated, Industrialized, Rich, and Democratic, see Henrich et al., 2010) countries with widespread availability of contraception methods that make testing this reasoning difficult. One recent study, conducted in a population with natural fertility control, has shown the opposite pattern - more creative people tended to have fewer rather than more children (Lebuda et al., in press). This finding has been interpreted as showing that creative people might maximize their reproductive success in a different way than by having more offspring. They instead tend to thoroughly plan the number of their children and try to make a better living for them (Lawson \& Mace, 2011). Does it mean, however, that creative adults are creative parents? 


\section{Adults' Creativity in Family and at Work}

Being a parent and being an employee are two specific roles that, for a great majority of people, occur only in adulthood. Both are challenging, so an obvious question might be is there a space for creativity as a parent and employee? As both family and work form two closely interrelated microsystems of emerging and established adults' functioning, their separation is somehow superficial, and we provide a separate overview of them just for the sake of clarity.

\section{Family}

Functioning creatively in the role of a parent quite easily evokes associations with parent-child play - a fuel for developing children's creativity (Hoffmann \& Russ, 2012). A number of studies shows that parents who spend time on playing with their children, especially if this play is pretend play (Russ, 1993), are more efficient in stimulating children's curiosity, imagination, and divergent thinking. Yet creative parenting is also considered a kind of lifestyle orientation (Kwaśniewska \& Lebuda, 2017), with flexibly managing different family-and-work related tasks and being open to children's needs. In a qualitative study of mothers, being creative was most often understood as being able to manage demands of different social roles effectively (Kwaśniewska \& Lebuda, 2017). Importantly, creativity was rarely mentioned in the context of thinking alone, not to mention artistic activities. Rather, it was linked with an activity that solves everyday problems and allows the child to be more open.

Another large $(N=3,073)$ study on mothers (Kwaśniewska et al., 2018) searched for certain parental attitudes that may promote a family climate that is conducive for creativity. Four such factors were established after the literature review and pilot studies. The first of them referred to the encouragement to experience variety and novelty. It denotes tolerance and an agreement to explore and test different ways of functioning. Indeed, there is a growing 
literature that not only shows that more creative people are more open (Karwowski \& Lebuda, 2016; Puryear et al., 2017), but also more tolerant (Groyecka, 2018) and that strengthening creativity may stimulate open-mindedness and tolerance (Groyecka et al., 2020; Kaufman, 2018). Thus, a parent who creates for their children a space for freedom could have a chance to raise them as creative individuals. That being said, obviously the exact level of freedom given to a child depends on many factors - primarily the child's age. Experimenting is a building block for creative learning (Beghetto, 2016), yet, when unsafe, it might have devastating consequences. After all, Richard Feynman once almost burnt his parents' house during his early experiments (Gleick, 1993).

The second factor that is part of the positive climate for creativity at home is encouraging children's nonconformity. As creativity is inevitably linked with originality, it becomes risky and sometimes even rebellious. Parents who — at least to some extent— encourage such rebellious creativity (see Karwowski, 2017; Karwowski \& Jankowska, 2016; Lassig, 2020) and support their children's independence might help them build creative selfefficacy necessary for creative functioning.

The third factor that Kwaśniewska and her colleagues (2018) theorize as critical for creative parenting at home is supporting children's perseverance while making creative efforts. This factor seems vital, as too often creativity is being equated with short-term, enjoyable activities that evoke flow (Tsai, 2012). Yet creative activity is also skills-based, requires training and domain-specific competencies. Therefore, wise building of perseverance and teaching kids that not everything is fun and easy seems especially relevant. While it is disputable whether creative people are characterized by a higher level of grit (Grohman et al., 2017) or conscientiousness (Reiter-Palmon et al., 2009) understood as traits, it goes without saying that perseverance while dealing with more long-term creative goals is a vital part of 
creative self-regulation. Thus, strengthening children's creative metacognition and creative self-regulation is indeed an important part of creative parenting.

The fourth and final factor is directly related to unconstrained imagination and described as an encouragement to fantasize (Kwaśniewska et al., 2018). Creative play with children, playing roles, or using programs that increase their motivation (e.g. Dziedziewicz et al., 2013) might serve as examples of such activities. As Dacey (1989) recognizes, in some families, imagination and creativity become an essential family value, relevant to the same extent as school grades or behaving well. Such prioritization of creativity might indeed form a building block for its development in children.

\section{Work}

An even brief summary of different nuances of creativity at work goes well beyond this chapter's scope. Indeed, there are hundreds of thousands of research papers devoted to creativity in work-settings, with a growing rate being published every year. Therefore, we resign from a detailed overview in favor of some general comments that seem especially relevant for the developmental perspective of creativity in adulthood.

It sounds like a cliché to emphasize the role of being creative in work settings these days. Indeed, there are good reasons why creativity is considered one of the most important qualities of the current century by CEOs (Tomasco, 2018; but see also Khessina et al., 2018). Several studies summarized the confluence of factors that make creativity in the workplace possible - from individual characteristics: cognitive (creative abilities, intelligence, expertise, curiosity), personality-based (openness, persistence), motivational (self-efficacy), to teamwork (Reiter-Palmon, 2017), leader-follower interactions (Reiter-Palmon \& Illies, 2004), all the way to the organizational climate that supports or hinders creativity (Hunter et al., 2007). Being creative in the workplace seems to require the same basic skill set as creativity in any other life area - sensitivity to problems, openness to new ideas, ability to generate new 
solutions, and persistence to defy the crowd and fight for the best ideas. At the same time, however, such creativity occurs in extraordinary social conditions, with specific organizational culture, communication patterns, leaders' behaviors - just to name a few. Thus, even if creative abilities might be considered a necessary condition for work-based creativity, this is by no means a sufficient condition. Even someone who is a highly original thinker will probably fail without communicating effectively with other team-members or when being unable to accept constructive critique. At the same though, individual-level factors explain a far more substantial portion of companies' effectiveness that it is usually assumed (Mollick, 2012), and a vital few experts within the team can create a difference that leads to creative successes (Zhang et al., 2020).

The period of emerging adulthood is naturally associated with the start of a professional career, quite naturally meaning the time of holding a follower rather than a leader position in the work structure. Although there is widespread belief that it is people who enter into adulthood that are the most successful entrepreneurs and startup creators (with Bill Gates or Mark Zuckerberg taken as examples), a recent study (Azoulay et al., 2020) demonstrated that the average age of creators of fastest-growing companies is 45 - the age of established rather than emerging adulthood. Thus, even if emerging adults indeed often experiment with their businesses, it seems that success in this domain shares the same conditions as other domains require, namely experience and expertise. Enthusiasm alone is not sufficient, and contrary to what Mark Zuckerberg once said (as cited in Cocker, 2007), young people are not necessarily smarter when it comes to creativity or innovation.

Emerging adulthood is associated with several tensions that may promote creativity, yet also form a threat to creative functioning. Take an example of energy and independence young people often present. On the one hand, such a tendency to break the rules and test the boundaries is vital for creative functioning (Petrou et al., 2018). On the other, however, it 
creates conflicts that might hinder creativity in work settings (Kurtzberg \& Mueller, 2005). Still, however, for emergent adults, the beginning of their careers forms a space for learning and experimenting. Having more experienced creative mentors (Wright \& Wright, 1987) allows for vicarious learning - one of the critical factors that build creative self-concept (Karwowski et al., 2019).

It is in established adulthood when people gain sufficient knowledge and experience to make full benefit from their creativity. Although this goes against the widely-accepted stereotype that more experienced workers are less creative, a meta-analysis ( $\mathrm{Ng} \&$ Feldman, 2013) shows quite the opposite - a small $(r=.07)$, yet significant, link between age and innovation-related behaviors in the workplace. Although such a small correlation might be considered practically meaningless, it does provide arguments against the perception of older workers as less creative.

Creativity in the workplace is primarily an activity. Abilities and certain personality traits are important, but only as factors that release willingness to engage in creative efforts and behave creatively. Similarly, leaders' behaviors, team-members' interactions, and overall creative climate are relevant as examples of such antecedents, mediators, and moderators of creativity at work. However, what seems crucial yet overlooked in explaining emerging and established adults' creativity at work is their self-concept. More specifically, we posit that defining oneself as a creative employee who values and engages in creative activity is a key factor in explaining work creativity (Petkus, 1996). It leads us to a broader theoretical operationalization of the role of creative self-beliefs (Karwowski et al., 2019) and thinking about creativity in adulthood in terms of the agentic decision.

\section{Creativity in Adulthood as Agentic Action}

Why do creative children so rarely become creative adults? Why don't their creative abilities translate into creative activities and achievements? Although a now-classic study 
(Plucker, 1999) found a robust correlation between divergent thinking in childhood and creative achievement in adulthood $(r=.60)$, most studies synthesized in a meta-analysis (Kim, 2008) demonstrate much weaker links (average $r=.22$ ). One of the perspectives explaining this mediocre correlation is seeing creativity as a special kind of agentic activity for which a decision is needed (Karwowski \& Beghetto, 2019), and abilities alone are not sufficient. The argument that follows is that most emerging and established adults simply decide not to engage in a creative activity (at least professionalized one) due to their lack of confidence in their creative abilities and — perhaps even more importantly—low value ascribed to creativity by the individual.

If creative abilities alone are unable to explain the likelihood of creative achievement in adulthood, what other elements should be considered here? Over the years, creativity literature reported a confluence of different factors, including personality (Feist \& Barron, 2003), identity (Helson \& Pals, 2000), but also interests (Feinstein, 2006), values (Runco et al., 2016), all the way to environmental (Richardson \& Mishra, 2018) and socio-political factors (Lebuda, 2016).

With the successive stages of creativity development, and especially in the case of mature and outstanding creativity, the motivational processes gain in importance. As Csikszentmihalyi (1985) observed, "[...] the unifying similarity among geniuses and innovators is not cognitive or affective but motivational. What is common among them is the unwillingness or inability to strive for goals everyone else accepts - their refusal to live by a presented life theme (p. 114)". Creativity is inherently polimotivational (see Anderson \& Karwowski, 2020), i.e. shaped by many different factors. Intrinsic and extrinsic motives can trigger each other and result in motivational synergy (Amabile, 1993; Amabile \& Pratt, 2016; Fischer et al., 2019). Indeed, the role of intrinsic motivation - undertaking activities out of sheer interest or enjoyment (Ryan \& Deci, 2000) - for creativity is well-established 
(Amabile, 1996; de Jesus et al., 2013; Liu et al., 2016; but see Byron \& Khazanchi, 2012). But creative activity in adulthood can also be supported by achievement motivation or even hubristic motivation, understood as exceeding one's achievements in a chosen field, connected with aspirations and ambitions (Kozielecki, 1987). Achieving creative goals requires that people become aware of them, make them more precise, and plan how they are going to meet them. As Ivcevic and Hoffmann (2019) propose, personal dispositions related to emotions (e.g. openness, willingness to take risks, internal motivation, passion) influence creativity by facilitating the decision to take creative action, guiding the choice of areas of activity, and altering the frequency of creative behavior. The ability to regulate emotions can provide a bridge between creative potential and creative achievements (Ivcevic \& Nusbaum, 2017), especially if accompanied by a high level of openness, passion, and perseverance (Ivcevic \& Brackett, 2015).

The creative behavior as agentic action (CBAA; Karwowski \& Beghetto, 2019) model posits that creative potential (e.g. divergent thinking) is a necessary yet not sufficient condition for creative behavior. Further, CBAA states that abilities are the building blocks of creative confidence: primarily creative self-concept and creative self-efficacy (Karwowski et al., 2019). Self-efficacy, including creative self-efficacy, develops through past successes and achievements, vicarious experience (e.g. observations of others), social influences (e.g. persuasion or supporting feedback), and physiological reactions. During development, individuals with higher creative abilities experience successes more often, receive positive information from their environment, and function among other people with creative achievements. All of this contributes to the development of their creative confidence. Thus, in development, creative abilities build creative confidence in a mediated way: through educational influences, prior successes, or positive feedback. There is evidence that creative 
self-efficacy increases in emerging adulthood (18-24) and stabilizes until established adulthood (Karwowski, 2015).

The second key element that determines the chance of realizing one's potential is valuing creativity: recognition of creativity as a worthwhile endeavor and a critical aspect of people's identity (creative personal identity, Jaussi et al., 2007). Valuing creativity moderates the link between potential and activity and - in a sense - releases potential. It is unlikely that individuals with even high creative abilities will achieve something spectacular if they do not consider creativity as valuable and meaningful. Paraphrasing Sternberg $(2002,2003)$, creativity requires not only a decision to make but also a road to take. During emerging adulthood - a period of intense creation and testing of different life-scenarios (see, e.g. de Valverde et al., 2017)—some people might seriously consider making such a decision. In established adulthood, however, when people are torn between family duties, caring about their career, and managing uncertain socio-economic reality, for many, professional creativity may mean a way too risky decision to make.

\section{Discussion}

Creativity as a construct and subject of research endeavors is complex and multifaceted. Indeed, we study and analyze its different forms and aspects, from 4Ps (Rhodes, 1961) to 5As (Glăveanu, 2013), to 7Cs (Lubart, 2017). We examine creative potential, activities, and profound achievements. To put it shortly, creativity in adulthood is not only a matter of having a creative potential— divergent thinking skills, imagination, or curiosity— but, to a large extent, of making specific decisions, usually accompanied by risk-taking (Beghetto et al., 2020; Sternberg \& Lubart, 1991, 1995), and effective utilization of one's resources. Creativity understood developmentally, with a special focus on adulthood, constitutes an act of free will (Simonton, 2017), and becoming a creative adult requires achieving independence and autonomy (Maslow, 1970). In that sense, creativity is not only a 
correlate of higher levels of human needs (see, e.g. Neubauer \& Martskvishvili, 2018); it might be considered one of the highest needs to achieve itself (Kaufman, 2020). However, this requires that creativity is valued as a way of everyday functioning, not only in an individual and professionalized sense of becoming scientists or artists, but also as a fundamental part of people's personal and role identity, as being a creative partner, parent, or employee (Karwowski \& Kaufman, 2017).

If we hence assume that creativity is a kind of decision, then investing in it during adulthood becomes more probable when one has appropriate developmental capital accumulated since early years. It is comprised of adequate intellectual, personality, motivational, and social resources that operate in confluent, compensatory, and non-linear manners (Sternberg \& Lubart, 1995). In the present chapter, we attempted to show that even though development is most frequently perceived as transformation from infant to adult, achievement of adulthood certainly does not equal stagnation on consecutive stages of life. On the contrary, it becomes a natural chance to fulfill one's creative potential, including real creative achievements. What is desired in adulthood is not just creative capital based on developmental achievements in previous dynamic phases of life, such as for instance identity achievement (Erikson, 1968), which is crucial in adolescence; postformal thinking (Wu \& Chiou, 2008); personality, which takes shape from childhood and stabilizes in the third decade of life (Terracciano et al., 2006); fluid intelligence (Kanfer \& Ackerman, 2004), which peaks in early adulthood; but also developing of new competences, experiencing unknown social roles, or realizing consecutive developmental tasks.

Summarizing our erstwhile deliberations, we may assume that the following are most frequent developmental tasks young adults face: establishing work or pursuing higher education, behaving appropriately in the workplace, committed romantic relationships or marriage, caring effectively for dependent children, maintaining a household, and 
establishing financial independence. Individuals who are on the stage of middle adulthood face the following tasks: maintaining satisfactory work, maintaining romantic relationships, launching children, adjusting to an "empty nest," civic engagement, attaining financial security, caring for aging parents, and adaptation to midlife physical changes (McCormick et al., 2011, p. 122). Rising to these and other challenges of adulthood comes hand in hand with the need for creative adaptation, which is based both on adjusting oneself to the requirements of the environment and on adjusting the environment to one's own ideas. This is done both on the level of external transformation of a field (sensitivity to context, awareness of any given domain's limitations, readiness for transforming it) and internal transformation of self (sensitivity to self, openness, need for change) (Cohen, 2012). In adulthood, the need for creatively shaping one's own path of life is also associated with the influence of historical and non-normative events, which are less determined by age or stage of development (Baltes et al., 1980), but are stronger than in previous stages of life.

The trajectory of creativity seems to differ depending on the level of creativity (fluid creativity, crystallized creativity, vs. mature creativity, eminent creativity), as well as creativity criteria (creative potential, productivity, creative achievements), both of which are rooted in the developmental approach. Creativity in adulthood inscribes itself in an emergent paradigm of nonlinear human development, which is obviously nonlinear, individual, multidimensional, and interconnected. If combines both quantitative and qualitative chances. It may most probably change rather than decrease along with age. Adoption of the model of creativity development during the course of the entire life and, consequently, its cyclical and phasic character, is associated with accepting potential crises. However, these crises could be considered change stimulators, breakthrough moments, and occasions for internal transformation (Dąbrowski, 1964). Adopting the perspective of "life-creativity" understood 
as a process of creating one's life-paths makes the trajectory of life of each human being exceptional (Zittoun \& de Saint Laurent, 2015). 


\section{References}

Adnan, A., Beaty, R., Lam, J., Spreng, R. N., \& Turner, G. R. (2019). Intrinsic defaultexecutive coupling of the creative aging brain. Social Cognitive and Affective Neuroscience, 14, 291-303. https://doi.org/10.1093/scan/nsz013

Adnan, A., Beaty, R., Silvia, P., Spreng, R. N., \& Turner, G. R. (2019). Creative aging: functional brain networks associated with divergent thinking in older and younger adults. Neurobiology of Aging, 75, 150-158.

https://doi.org/10.1016/j.neurobiolaging.2018.11.004

Albert, R. S. (1990). Identity, experiences, and career choice among the exceptionally gifted and eminent. In M. A. Runco \& R. S. Albert (Eds.), Sage focus editions, Vol. 115. Theories of creativity (p. 13-34). Sage Publications, Inc.

Alpaugh, P. K., \& Birren, J. E. (1977). Variables affecting creative contributions across the adult lifespan. Human Development, 20(4), 240-248. https://doi.org/10.1159/000271559.

Alpaugh, P. K., Parham, I. A., Cole, K. D., \& Birren, J. E. (1982). Creativity in adulthood and old age: An exploratory study. Educational Gerontology, 8(2), 101-116. https://doi.org/10.1080/0380127820080202

Amabile, T. M. (1993). Motivational synergy: Toward new conceptualizations of intrinsic and extrinsic motivation in the workplace. Human Resource Management Review, 3(3), 185-201. https://doi.org/10.1016/1053-4822(93)90012-S

Amabile, T. M. (1996). Creativity in context. Routledge. https://doi.org/10.4324/9780429501234

Amabile, T. M., \& Pratt, M. G. (2016). The dynamic componential model of creativity and innovation in organizations: Making progress, making meaning. Research in Organizational Behavior, 36, 157-183. https://doi.org/10.1016/j.riob.2016.10.001 
Anderson, R., \& Karwowski, M. (2020). Motivation and creativity. In M. Runco and S. Pritzker (Eds.), Encyclopedia of creativity, third edition (pp. 185-189). Elsevier.

Arnett, J. J. (2000). Emerging adulthood: A theory of development from the late teens through the twenties. American Psychologist, 55(5), 469-480. https://doi.org/10.1037/0003-066X.55.5.469

Årseth, A. K., Kroger, J., Martinussen, M., \& Marcia, J. E. (2009). Meta-analytic studies of identity status and the relational issues of attachment and intimacy. Identity, 9, 1-32. https://doi.org/10.1080/15283480802579532

Azoulay, P., Jones, B. F., Kim, J. D., \& Miranda, J. (2020). Age and high-growth entrepreneurship. American Economic Review: Insights, 2(1), 65-82. https://doi.org/10.1257/aeri.20180582

Baas, M., De Dreu, C. K. W., \& Nijstad, B. A. (2008). A meta-analysis of 25 years of moodcreativity research: Hedonic tone, activation, or regulatory focus? Psychological Bulletin, 134(6), 779-806. https://doi.org/10.1037/a0012815

Baltes, P. B., Reese, H. W., \& Lipsitt, L. P. (1980). Life-span developmental psychology. Annual Review of Psychology, 31, 65-110. https://doi.org/10.1146/annurev.ps.31.020180.000433

Beaumont, S. L., \& Pratt, M. M. (2011). Identity processing styles and psychosocial balance during early and middle adulthood: The role of identity intimacy and generativity. Journal of Adult Development, 18, 172-183. https://doi.org/10.1007/s10804-011$9125-\mathrm{z}$

Beaussart, M., Kaufman, S., \& Kaufman, J. (2012). Creative activity, personality, mental illness, and short-term mating success. Journal of Creative Behavior, 46(3), 151-167. https://doi.org/10.1002/jocb.11 
Beghetto, R. A. (2016). Creative learning: A fresh look. Journal of Cognitive Education and Psychology, 15(1), 6-23. https://doi.org/10.1891/1945-8959.15.1.6

Beghetto, R. A., \& Corazza, G. E. (Eds.). (2019). Dynamic perspectives on creativity: New directions for theory, research, and practice in education. Springer.

Beghetto, R. A., Karwowski, M., \& Reiter-Palmon, R. (2020). Intellectual risk taking: A moderating link between creative confidence and creative behavior? Psychology of Aesthetics, Creativity, and the Arts. Advance online publication.

https://doi.org/10.1037/aca0000323

Beghetto, R. A., \& Kaufman, J. C. (2007). Toward a broader conception of creativity: A case for "mini-c" creativity. Psychology of Aesthetics, Creativity, and the Arts, 1(2), 7379. https://doi.org/10.1037/1931-3896.1.2.73

Benedek, M., Bruckdorfer, R., \& Jauk, E. (2019). Motives for creativity: Exploring the what and why of everyday creativity. Journal of Creative Behavior. https://doi.org/10.1002/jocb.396

Benedek, M., Jauk, E., Sommer, M., Arendasy, M., \& Neubauer, A. C. (2014). Intelligence, creativity, and cognitive control: The common and differential involvement of executive functions in intelligence and creativity. Intelligence, 46, 73-83. https://doi.org/10.1016/j.intell.2014.05.007

Buss, D., \& Barnes, M. (1986). Preferences in human mate selection. Journal of Personality and Social Psychology, 50(3), 559-570. https://doi.org/10.1037/0022-3514.50.3.559

Buss, D. M. (1989). Sex differences in human mate preferences: Evolutionary hypotheses tested in 37 cultures. Behavioral and Brain Sciences, 12(1), 1-14.

https://doi.org/10.1017/S0140525X00023992 
Byron, K., \& Khazanchi, S. (2012). Rewards and creative performance: A meta-analytic test of theoretically derived hypotheses. Psychological Bulletin, 138(4), 809-830. https://doi.org/10.1037/a0027652

Cattell, R. B. (1963). Theory of fluid and crystallized intelligence: A critical experiment. Journal of Educational Psychology, 54(1), 1-22. https://doi.org/10.1037/h0046743

Clegg, H., Nettle, D., \& Miell, D. (2008). A test of Miller's aesthetic fitness hypothesis. Journal of Evolutionary Psychology, 6, 101-115. https://doi.org/10.1556/jep.2008.1009

Clegg, H., Nettle, D., \& Miell, D. (2011). Status and mating success amongst visual artists. Frontiers in Psychology, 2. https://doi.org/10.3389/fpsyg.2011.00310

Cocker, M. (2007). Startup advice for entrepreneurs from Y combinator. VentureBeat, Retrieved from https://venturebeat.com/2007/03/26/start-up-advice-for-entrepreneursfrom-y-combinator-startup-school/

Cohen, L. M. (1989). A continuum of adaptive creative behaviors. Creativity Research Journal, 2(3), 169-183. https://doi.org/10.1080/10400418909534313

Cohen, L. M. (2009). Linear and network trajectories in creative lives: A case study of Walter and Roberto Burle Marx. Psychology of Aesthetics, Creativity, and the Arts, 3(4), 238-248. https://doi.org/10.1037/a0015495

Cohen, L. M. (2012). Adaptation and creativity in cultural context. Revista de Psicología, 30, 3-18. Retrieved from http://www.scielo.org.pe/pdf/psico/v30n1/a01v30n1

Conner, T. S., DeYoung, C. G., \& Silvia, P. J. (2018). Everyday creative activity as a path to flourishing. Journal of Positive Psychology, 13(2), 181-189. https://doi.org/10.1080/17439760.2016.1257049 
Conner, T. S., \& Silvia, P. J. (2015). Creative days: A daily diary study of emotion, personality, and everyday creativity. Psychology of Aesthetics, Creativity, and the Arts, 9(4), 463-470. https://doi.org/10.1037/aca0000022

Csikszentmihalyi, M. (1985). Emergent motivation and the evolution of the self: Motivation in adulthood. In D. Kleiber \& M. H. Maehr (Eds.), Advances in motivation and achievement (Vol. 4, pp. 93-119). JAI Press.

Csikszentmihalyi, M. (1988). Society, culture, and person: A system view of creativity. In R. J. Sternberg (Ed.), The nature of creativity (pp. 76-98). Cambridge University Press.

Dąbrowski, K. (1964). Positive disintegration. Little Brown.

Dacey, J. S. (1989). Peak periods of creative growth across the lifespan. Journal of Creative Behavior, 23(4), 224-247. https://doi.org/10.1002/j.2162-6057.1989.tb00697.x

Davis, M. A. (2009). Understanding the relationship between mood and creativity: A metaanalysis. Organizational Behavior and Human Decision Processes, 108(1), 25-38. https://doi.org/10.1016/j.obhdp.2008.04.001

de Jesus, S. N., Rus, C. L., Lens, W., \& Imaginário, S. (2013). Intrinsic motivation and creativity related to product: A meta-analysis of the studies published between 19902010. Creativity Research Journal, 25(1), 80-84.

https://doi.org/10.1080/10400419.2013.752235

de Valverde, J., Sovet, L., \& Lubart, T. (2017). Self-construction and creative "life design". In M. Karwowski \& J. C. Kaufman (Eds.), The creative self (pp. 99-115). Academic Press.

Dollinger, S. J., Dollinger, S. M. C., \& Centeno, L. (2005). Identity and Creativity. Identity: An International Journal of Theory and Research, 5(4), 315-339. https://doi.org/10.1207/s1532706xid0504_2 
Dziedziewicz, D., Oledzka, D., \& Karwowski, M. (2013). Developing 4-to 6-year-old children's figural creativity using a doodle-book program. Thinking Skills and Creativity, 9, 85-95. https://doi.org/10.1016/j.tsc.2012.09.004

Ericsson, K. A., \& Charness, N. (1994). Expert performance: Its structure and acquisition. American Psychologist, 49(8), 725-747. https://doi.org/10.1037/0003-066X.49.8.725

Ericsson, K. A., Krampe, R. T., \& Tesch-Römer, C. (1993). The role of deliberate practice in the acquisition of expert performance. Psychological Review, 100(3), 363-406.

Erikson, E. H. (1968). Identity youth and crisis. Norton \& Company.

Erikson, E. H. (1982). The life cycle completed. Norton \& Company.

Feinstein, J. S. (2006). The nature of creative development. Stanford University Press.

Feist, G. J., \& Barron, F. X. (2003). Predicting creativity from early to late adulthood: Intellect, potential, and personality. Journal of Research in Personality, 37(2), 62-88. https://doi.org/10.1016/S0092-6566(02)00536-6

Feldman, D. H. (1994). Beyond universals in cognitive development (2nd ed.). Norwood, NJ: Ablex.

Feldman, D. H. (1999). The development of creativity. In R. J. Sternberg (Ed.), Handbook of creativity (pp. 169-188). Cambridge University Press.

Fischer, C., Malycha, C., \& Schafmann, E. (2019). The influence of intrinsic motivation and synergistic extrinsic motivators on creativity and innovation. Frontiers in Psychology. https://doi.org/10.3389/fpsyg.2019.00137

Foos, P. W., \& Boone, D. (2008). Adult age differences in divergent thinking: it's just a matter of time. Educational Gerontology, 34(7), 587-594.

https://doi.org/10.1080/03601270801949393 
Freud, S. (1915/1958). The unconscious. In J. Strachey (Ed. \& Trans.), The standard edition of the complete psychological works of Sigmund Freud (Vol. 14, pp. 159-215). Hogarth Press. (Original work published 1915)

Geher, G., \& Kaufman, S. (2013). Mating intelligence unleashed. Oxford University Press. Glăveanu, V. P. (2013). Rewriting the language of creativity: The Five A's framework. Review of General Psychology, 17, 69-81. https://doi.org/10.1037/a0029528

Gleick, J. (1993). Genius: The Life and Science of Richard Feynman. Vintage Books.

Gocłowska, M. A., Ritter, S. M., Elliot, A. J., \& Baas, M. (2019). Novelty seeking is linked to openness and extraversion, and can lead to greater creative performance. Journal of Personality, 87(2), 252-266. https://doi.org/10.1111/jopy.12387

Gralewski, J., Lebuda, I., Gajda, A., Jankowska, D. M., \& Wiśniewska, E. (2016). Slumps and jumps: Another look at developmental changes in creative abilities. Creativity: Theories-Research-Applications, 3(1), 152-177. https://doi.org/10.1515/ctra-20160011

Grohman, M. G., Ivcevic, Z., Silvia, P., \& Kaufman, S. B. (2017). The role of passion and persistence in creativity. Psychology of Aesthetics, Creativity, and the Arts, 11(4), 376-385. https://doi.org/10.1037/aca0000121

Groyecka, A. (2018). Will becoming more creative make us more tolerant? Creativity: Theories-Research-Applications, 5(2), 170-176. https://doi.org/10.1515/ctra-20180015

Groyecka, A., Gajda, A., Jankowska, D. M., Sorokowski, P., \& Karwowski, M. (2020). On the benefits of thinking creatively: Why does creativity training strengthen intercultural sensitivity among children. Thinking Skills and Creativity, 37, 100693. https://doi.org/10.1016/j.tsc.2020.100693

Guilford, J. P. (1967). The nature of human intelligence. McGraw-Hill. 
Hardy, J. H., Ness, A. M., \& Mecca, J. (2017). Outside the box: Epistemic curiosity as a predictor of creative problem solving and creative performance. Personality and Individual Differences, 104, 230-237. https://doi.org/10.1016/j.paid.2016.08.004

Hass, R. W., \& Weisberg, R. W. (2015). Revisiting the 10-year rule for composers from the Great American Songbook: On the validity of two measures of creative production. Psychology of Aesthetics, Creativity, and the Arts, 9(4), 471-479. https://doi.org/10.1037/aca0000021

Hayes, J. R. (1989). The complete problem solver (2nd ed.). Erlbaum.

Helson, R., \& Pals, J. L. (2000). Creative potential, creative achievement, and personal growth. Journal of Personality, 68(1), 1-27. https://doi.org/10.1111/1467-6494.00089

Henrich, J., Heine, S. J., \& Norenzayan, A. (2010). The weirdest people in the world? Behavioral and Brain Sciences, 33(2-3), 61-83. https://doi.org/10.1017/S0140525X0999152X

Hoffmann, J., \& Russ, S. (2012). Pretend play, creativity, and emotion regulation in children. Psychology of Aesthetics, Creativity, and the Arts, 6(2), 175-184. https://doi.org/10.1037/a0026299

Hoffmann, J. D., \& Russ, S. W. (2016). Fostering pretend play skills and creativity in elementary school girls: A group play intervention. Psychology of Aesthetics, Creativity, and the Arts, 10(1), 114-125. https://doi.org/10.1037/aca0000039

Hunter, S. T., Bedell, K. E., \& Mumford, M. D. (2007). Climate for creativity: A quantitative review. Creativity Research Journal, 19(1), 69-90. https://doi.org/10.1080/10400410709336883

Ivcevic, Z., \& Brackett, M. A. (2015). Predicting creativity: Interactive effects of openness to experience and emotion regulation ability. Psychology of Aesthetics, Creativity, and the Arts, 9(4), 480-487. https://doi.org/10.1037/a0039826 
Ivcevic, Z., \& Hoffmann, J. (2019). Emotions and creativity. In J. C. Kaufman, R. J. Sternberg (Eds.), The Cambridge handbook of creativity (pp. 273-295). Cambridge University Press.

Ivcevic, Z., \& Nusbaum, E. C. (2017). From having an idea to doing something with it: Selfregulation for creativity. In M. Karwowski, J. C. Kaufman (Eds.), The creative self: How our beliefs, self-efficacy, mindset, and identity impact our creativity (pp. 343365). Academic Press. https://doi.org/10.1016/B978-0-12-809790-8.00020-0

Jaquish, G. A., \& Ripple, R. E. (1984). Adolescent divergent thinking: A cross-cultural perspective. Journal of Cross-Cultural Psychology, 15(1), 95-104. https://doi.org/10.1177/0022002184015001006

Jaussi, K. S., Randel, A. E., \& Dionne, S. D. (2007). I am, I think I can, and I do: The role of personal identity, self-efficacy, and cross-application of experiences in creativity at work. Creativity Research Journal, 19(2-3), 247-258.

https://doi.org/10.1080/10400410701397339

Kanazawa, S. (2000). Scientific discoveries as cultural displays: A further test of Miller's courtship model. Evolution and Human Behavior, 21(5), 317-321. https://doi.org/10.1016/S1090-5138(00)00051-9

Kanfer, R., \& Ackerman, P. L. (2004). Aging, Adult Development, and Work Motivation. The Academy of Management Review, 29(3), 440-458. https://doi.org/10.2307/20159053

Karwowski, M. (2015). Development of the Creative Self-Concept, Creativity. Theories Research - Applications, 2(2), 165-179. https://doi.org/10.1515/ctra-2015-0019

Karwowski, M. (2017). Subordinated and rebellious creativity at school. In R. A. Beghetto and B. Sriraman (Eds.). Creative contradictions in education (pp. 89-114). Springer. https://doi.org/10.1007/978-3-319-21924-0_6 
Karwowski, M., \& Beghetto, R. A. (2019). Creative behavior as agentic action. Psychology of Aesthetics, Creativity, and the Arts, 13(4), 402-415. https://doi.org/10.1037/aca0000190

Karwowski, M., \& Brzeski, A. (2017). Selfies and the (creative) self: a diary study. Frontiers in Psychology, 8, 172. https://doi.org/10.3389/fpsyg.2017.00172

Karwowski, M., \& Jankowska, D. M. (2016). Four faces of creativity at school. In. R. A. Beghetto \& J. C. Kaufman (Eds.) Nurturing creativity in the classroom. Cambridge University Press.

Karwowski, M., \& Lebuda, I. (2016). The big five, the huge two, and creative self-beliefs: A meta-analysis. Psychology of Aesthetics, Creativity, and the Arts, 10(2), 214-232. https://doi.org/10.1037/aca0000035

Karwowski, M., Lebuda, I., \& Beghetto, R. A. (2019). Creative self-beliefs. In J. C. Kaufman \& R. J. Sternberg (Eds.), The Cambridge handbook of creativity (pp. 396-417). Cambridge University Press.

Karwowski, M., Lebuda, I., Szumski, G., \& Firkowska-Mankiewicz, A. (2017). From moment-to-moment to day-to-day: Experience sampling and diary investigations in adults' everyday creativity. Psychology of Aesthetics, Creativity, and the Arts, 11(3), 309-324. https://doi.org/10.1037/aca0000127

Kaufman, J. C. (2018). Creativity's need for relevance in research and real life: Let's set a new agenda for positive outcomes. Creativity: Theories-Research-Applications, 5, 124-137. https://doi.org/10.1515/ctra-2018-0008

Kaufman, J. C., \& Beghetto, R. A. (2009). Beyond big and little: The Four C Model of creativity. Review of General Psychology, 13, 1-12. https://doi.org/10.1037/a0013688

Kaufman, S. B. (2020). Transcend: The new science of self-actualization. JP Tarcher US/Perigee Bks. 
Kaufman, S. B., \& Kaufman, J. C. (2007). Ten years to expertise, many more to greatness: An investigation of modern writers. Journal of Creative Behavior, 41(2), 114-124. https://doi.org/10.1002/j.2162-6057.2007.tb01284.x

Kerns, J. G. (2006). Anterior cingulate and prefrontal cortex activity in an fMRI study of trial-to-trial adjustments on the Simon task. NeuroImage, 33, 339-405. doi: 10.1016/j.neuroimage.2006.06.012

Kerns, J. G., Cohen, J. D., MacDonald, A. W. III., Cho., R. Y., Stenger, V. A., \& Carter, C. S. (2004). Anterior Cingulate Conflict Monitoring and Adjustments in Control. Science, 303(5660), 1023-1026. https://doi.org/10.1126/science.1089910

Khessina, O. M., Goncalo, J. A., \& Krause, V. (2018). It's time to sober up: The direct costs, side effects and long-term consequences of creativity and innovation. Research in Organizational Behavior, 38, 107-135. https://doi.org/10.1016/j.riob.2018.11.003

Kilgour, M. (2006). Improving the creative process: Analysis of the effects of divergent thinking techniques and domain specific knowledge on creativity. International Journal of Business and Society, 7, 79-107.

Kim, K. H. (2008). Meta-analyses of the relationship of creative achievement to both IQ and divergent thinking test scores. Journal of Creative Behavior, 42(2), 106-130. https://doi.org/10.1002/j.2162-6057.2008.tb01290.x

Kleibeuker, S. W., De Dreu, C. K. W., \& Crone, E. A. (2013). The development of creative cognition across adolescence: distinct trajectories for insight and divergent thinking. Developmental Science, 16(1), 2-12. doi: 10.1111/j.1467-7687.2012.01176.x.

Kohlberg, L. (1987). The development of moral judgment and moral action. In L. Kohlberg (Ed.), Child psychology and childhood education. A cognitive developmental view. Longman. 
Kozielecki, J. (1987). The role of hubristic motivation in transgressive behavior. New Ideas in Psychology, 5(3), 361-383. https://doi.org/10.1016/0732-118X(87)90006-7

Kurtzberg, T. R., \& Mueller, J. S. (2005). The influence of daily conflict on perceptions of creativity: A longitudinal study. International Journal of Conflict Management, 16, $335-353$.

Kwaśniewska, J. M., Gralewski, J., Witkowska, E. M., Kostrzewska, M., \& Lebuda, I. (2018). Mothers' personality traits and the climate for creativity they build with their children. Thinking Skills and Creativity, 27, 13-24. https://doi.org/10.1016/j.tsc.2017.11.002

Kwaśniewska, J. M., \& Lebuda, I. (2017). Balancing between roles and duties-The creativity of mothers. Creativity: Theories-Research-Applications, 4, 137-158. https://doi.org/10.1515/ctra-2017-0007

Lange, B., \& Euler, H. (2014). Writers have groupies, too: High quality literature production and mating success. Evolutionary Behavioral Sciences, 8(1), 20-30. https://doi.org/10.1037/h0097246

Lassig, C. (2020). A typology of student creativity: Creative personal expression, boundary pushing and task achievement. Thinking Skills and Creativity, 36, 100654. https://doi.org/10.1016/j.tsc.2020.100654

Lawson, D., \& Mace, R. (2011). Parental investment and the optimization of human family size. Philosophical Transactions of the Royal Society B: Biological Sciences, 366, 333-343. https://doi.org/10.1098/rstb.2010.0297

Lebuda, I. (2016). Political pathologies and Big-C creativity: Eminent Polish creators' experience of restrictions under the communist regime. In V. P. Glaveanu (Ed.), The Palgrave handbook of creativity and culture research (pp. 329-354). Palgrave Macmillan. 
Lebuda, I., \& Csikszentmihalyi, M. (2020). All you need is love: The importance of partner and family relations to highly creative individuals' well-being and success. Journal of Creative Behavior, 54, 100-114. https://doi.org/10.1002/jocb.348

Lebuda, I., Sorokowski, P., Groyecka-Bernard, A., Marczak, M., Gajda, A., Jankowska, D. M., \& Karwowski, M. (in press). Creation and procreation: Creative ability and reproductive success outside the WEIRD world. Creativity Research Journal.

Lehman, H. C. (1953). Age and achievement. Princeton University Press.

Levinson, D. J. (1986). A conception of adult development. American Psychologist, 41, 3-13.

Levy, B., \& Langer, E. (1999). Aging. In M. A. Runco, S. R. Pritzker (Eds.), Encyclopedia of creativity (pp. 45-52). Academic Press.

Li, N. P., \& Kenrick, D. T. (2006). Sex similarities and differences in preferences for shortterm mates: what, whether, and why. Journal of Personality and Social Psychology, $90(3), 468-489$.

Liu, D., Jiang, K., Shalley, C. E., Keem, S., \& Zhou, J. (2016). Motivational mechanisms of employee creativity: A meta-analytic examination and theoretical extension of the creativity literature. Organizational Behavior and Human Decision Processes, 137, 236-263. https://doi.org/10.1016/j.obhdp.2016.08.001

Lubart, T. (2017). The 7 c's of creativity. Journal of Creative Behavior, 51(4), 293-296. https://doi.org/10.1002/jocb.190

Luyckx, K., Schwartz, S. J., Berzonsky, M. D., Soenens, B., Vansteenkiste, M., Smits, I., \& Goossens, L. (2008). Capturing ruminative exploration: Extending the fourdimensional model of identity formation in late adolescence. Journal of Research in Personality, 42(1), 58-82. https://doi.org/10.1016/j.jrp.2007.04.004 
Madore, K. P., Jing, H. G., \& Schacter, D. L. (2016). Divergent creative thinking in young and older adults: extending the effects of an episodic specificity induction. Memory \& Cognition, 44(6), 974-88. https://doi.org/10.3758/s13421-016-0605-z

Marcia, J. E. (2002). Identity and psychosocial development in adulthood. Identity: An International Journal of Theory and Research, 2(1), 7-28. https://doi.org/10.1207/S1532706XID0201_02

Martindale, C. (1999). Biological basis of creativity. In R. J. Sternberg (Eds.), Handbook of creativity (pp. 137-152). Cambridge University Press.

Maslow, A. H. (1970). Motivation and personality (2nd ed.). Harper \& Row.

McAdams, D. P., \& Logan, R. L. (2004). What is generativity? In E. de St. Aubin, D. P. McAdams, \& T.-C. Kim (Eds.), The generative society: Caring for future generations (p. 15-31). American Psychological Association. https://doi.org/10.1037/10622-002

McCormick, C. M., Kuo, S. I.-C., \& Masten, A. S. (2011). Developmental tasks across the life span. In K. L. Fingerman, C. A. Berg, J. Smith, \& T. C. Antonucci (Eds.), Handbook of life-span development (p. 117-139). Springer Publishing Company.

McCrae, R. R., Arenberg, D., \& Costa, P. T. (1987). Declines in divergent thinking with age: Cross-sectional, longitudinal, and cross-sequential analyses. Psychology and Aging, 2, 130-137. doi:10.1037/0882-7974.2.2.130

Mehta, C. M., Arnett, J. J., Palmer, C. G., \& Nelson, L. J. (2020). Established adulthood: A new conception of ages 30 to 45. American Psychologist, 75(4), 431-444. https://doi.org/10.1037/amp0000600

Miller, G. (1999). Sexual selection for cultural displays. In R. Dunbar, C. Knight, \& C. Power (Eds.), The evolution of culture (pp. 1-16). Edinburgh University Press. Miller, G. (2000). The mating mind. How sexual choice shaped the evolution of human nature. Doubleday. 
Miller, G. (2008). How mate choice shaped human nature: A review of sexual selection and human evolution. In C. Crawford, \& D. Krebs (Eds.), Handbook of evolutionary psychology: Ideas, issues, and applications (pp. 87-129). Lawrence Erlbaum.

Miroshnik, K. G., \& Shcherbakova, O. V. (2019). The proportion and creativity of "old" and "new" ideas: Are they related to fluid intelligence? Intelligence, 76, 101384. https://doi.org/10.1016/j.intell.2019.101384

Mollick, E. (2012). People and process, suits and innovators: The role of individuals in firm performance. Strategic Management Journal, 33, 1001-1015. https://doi.org/10.1002/smj.1958

Nęcka, E. (2001). Psychologia twórczości (Psychology of creativity). Gdańsk: GWP.

Nęcka, E., Grohman, M., \& Slabosz, A. (2006). Creativity studies in Poland. In J. C. Kaufman \& R. J. Sternberg (Eds.). The international handbook of creativity. (pp. 270306), Cambridge University Press. https://doi.org/10.1017/CBO9780511818240.010

Nettle, D. (2008). Why is creativity attractive in a potential mate? Behavioral and Brain Sciences, 31(3), 275-276. https://doi.org/10.1017/S0140525X08004366

Neubauer, A. C., \& Martskvishvili, K. (2018). Creativity and intelligence: A link to different levels of human needs hierarchy?. Heliyon, 4(5). doi: 10.1016/j.heliyon.2018.e00623

Ng, T. W., \& Feldman, D. C. (2013). A meta-analysis of the relationships of age and tenure with innovation-related behaviour. Journal of Occupational and Organizational Psychology, 86(4), 585-616. https://doi.org/10.1111/joop.12031

Palmiero, M. (2015). The effects of age on divergent thinking and creative objects production: a cross-sectional study. High Ability Studies, 26(1), 93-104. https://doi.org/10.1080/13598139.2015.1029117 
Palmiero, M., Di Giacomo, D., \& Passafiume, D. (2014). Divergent thinking and age-related changes. Creativity Research Journal, 26(4), 456-460. https://doi.org/10.1080/10400419.2014.961786

Petkus, E. D. (1996). The creative identity: Creative behavior from the symbolic interactionist perspective. Journal of Creative Behavior, 30(3), 188-196. https://doi.org/10.1002/j.2162-6057.1996.tb00768.x

Petrou, P., van der Linden, D., \& Salcescu, O. C. (2018). When breaking the rules relates to creativity: The role of creative problem-solving demands and organizational constraints. Journal of Creative Behavior, 54(1), 184-195. https://doi.org/10.1002/jocb.354

Piaget, J. (1928/1959). Judgment and reasoning in the child. Littlefield, Adams, \& Co (original work published in 1928).

Plucker, J. A. (1999). Is the proof in the pudding? Reanalyses of Torrance's (1958 to present) longitudinal data. Creativity Research Journal, 12(2), 103-114. https://doi.org/10.1207/s15326934crj1202_3

Prokosch, M., Coss, R., Scheib, J., \& Blozis, S. (2009). Intelligence and mate choice: Intelligent men are always appealing. Evolution and Human Behavior, 30(1), 11-20. https://doi.org/10.1016/j.evolhumbehav.2008.07.004

Puryear, J. S., Kettler, T., \& Rinn, A. N. (2017). Relationships of personality to differential conceptions of creativity: A systematic review. Psychology of Aesthetics, Creativity, and the Arts, 11(1), 59-68. https://doi.org/10.1037/aca0000079

Reese, H. W., Lee, L. J., Cohen, S. H., \& Puckett, J. M., Jr. (2001). Effects of intellectual variables, age, and gender on divergent thinking in adulthood. International Journal of Behavioral Development, 25(6), 491-500.

Reiter-Palmon, R. (Ed.). (2017). Team creativity and innovation. Oxford University Press. 
Reiter-Palmon, R., \& Illies, J. J. (2004). Leadership and creativity: Understanding leadership from a creative problem-solving perspective. Leadership Quarterly, 15(1), 55-77. https://doi.org/10.1016/j.leaqua.2003.12.005

Reiter-Palmon, R., Illies, J. J., \& Kobe-Cross, L. M. (2009). Conscientiousness is not always a good predictor of performance: The case of creativity. International Journal of Creativity \& Problem Solving, 19(2), 27-45.

Rhodes, M. (1961). An analysis of creativity. The Phi Delta Kappan, 42(7), 305310.Richards, R. (1994/2017). Everyday Creativity: Coping and Thriving in the 21st Century. Lulu.

Richards, R. (2007). Everyday creativity: Our hidden potential. In R. Richards (Ed.), Everyday creativity and new views of human nature (pp. 25-54). American Psychological Association. https://doi.org/10.1037/11595-001

Richardson, C., \& Mishra, P. (2018). Learning environments that support student creativity: Developing the SCALE. Thinking Skills and Creativity, 27, 45-54. https://doi.org/10.1016/j.tsc.2017.11.004

Root-Bernstein, R. S. (1999). Productivity and age. In M. A. Runco, S. R. Pritzker (Eds.), Encyclopedia of creativity (pp. 457-463). Academic Press.

Root-Bernstein, R. S., \& Root-Bernstein, M. M. (2011). Life stages of creativity. In M. Runco \& S. Pritzker (Eds.), The Encyclopedia of creativity (2nd ed., pp. 47-55). Elsevier.

Roskos-Ewoldsen, B., Black, S., \& McCown, S. (2008). Age-related changes in creative thinking. Journal of Creative Behavior, 42(1), 33-59. https://doi.org/10.1002/j.21626057.2008.tb01079.x

Rothenberg, A. (1990). Creativity in adolescence. Psychiatric Clinics of North America, 13(3), 415-434. 
Rowatt, W., DeLue, S., Strickhouser, L., \& Gonzalez, T. (2001). The limited influence of self-monitoring on romantic partner preferences. Personality and Individual Differences, 31(6), 943-954. https://doi.org/10.1016/S0191-8869(00)00197-5

Runco, M. A. (1996). Personal creativity: Definition and developmental issues. New Directions for Child Development, 72, 3-30. https://doi.org/10.1002/cd.23219967203

Runco, M. A. (2014). Creativity. Theories and themes: research, development, and practice, 2nd ed. Elsevier Academic Press.

Runco, M. A., \& Acar, S. (2012). Divergent thinking as an indicator of creative potential. Creativity Research Journal, 24(1), 66-75. https://doi.org/10.1080/10400419.2012.652929

Runco, M. A., Hao, N., Acar, S., Yang, J., \& Tang, M. (2016). The social "cost" of working in groups and impact on values and creativity. Creativity: Theories-ResearchApplications, 3(2), 229-243. https://doi.org/10.1515/ctra-2016-0015

Russ, S. W. (1993). Affect and creativity: The role of affect and play in creative process. Erlbaum.

Ryan, R. M., \& Deci, E. L. (2000). Self-determination theory and the facilitation of intrinsic motivation, social development, and well-being. American Psychologist, 55, 68-78. https://doi.org/10.1037/0003-066x.55.1.68

Sawyer, R. K. (2003). Introduction. In R. K. Sawyer, V. John-Steiner, S. Moran, R. J. Sternberg, D. H. Feldman, J. Nakamura, M. Csikszentmihályi (Eds.), Creativity and development (pp. 3-11). Oxford University Press.

Schutte, N. S., \& Malouff, J. M. (2019). A meta-analysis of the relationship between curiosity and creativity. Journal of Creative Behavior. doi:10.1002/jocb.421

Silvia, P. J., Beaty, R. E., Nusbaum, E. C., Eddington, K. M., Levin-Aspenson, H., \& Kwapil, T. R. (2014). Everyday creativity in daily life: An experience-sampling study of "little 
c" creativity. Psychology of Aesthetics, Creativity, and the Arts, 8(2), 183-188. https://doi.org/10.1037/a0035722

Silvia, P. J., Christensen, A. P., \& Cotter, K. N. (2016). Commentary: The development of creativity-Ability, motivation, and potential. New Directions for Child and Adolescent Development, 151, 111-119. https://doi.org/10.1002/cad.20147

Silvia, P. J., Nusbaum, E. C., \& Beaty, R. E. (2017). Old or new? Evaluating the old/new scoring method for divergent thinking tasks. Journal of Creative Behavior, 51(3), 216-224. https://doi.org/10.1002/jocb.101

Silvia, P. J., Wigert, B., Reiter-Palmon, R., \& Kaufman, J. C. (2012). Assessing creativity with self-report scales: A review and empirical evaluation. Psychology of Aesthetics, Creativity, and the Arts, 6(1), 19-34. https://doi.org/10.1037/a0024071

Simon, H. A., \& Chase, W. G. (1973). Skill in chess. American Scientist, 61, 394-403.

Simonton, D. K. (1988). Age and outstanding achievement: What do we know after a century of research? Psychological Bulletin, 104(2), 251-267. https://doi.org/10.1037/00332909.104.2.251

Simonton, D. K. (1994). Greatness: who makes history and why. New York: Guilford Press.

Simonton, D. K. (1997). Creative productivity: A predictive and explanatory model of career trajectories and landmarks. Psychological Review, 104(1), 66-89. https://doi.org/10.1037/0033-295X.104.1.66

Simonton, D. K. (2009). Varieties of (scientific) creativity: A hierarchical model of domainspecific disposition, development, and achievement. Perspectives on Psychological Science, 4, 441-452. https://doi.org/10.1111/j.1745-6924.2009.01152.x

Simonton, D. K. (2012). Creative productivity and aging: An age decrement—Or not? In S. K. Whitbourne \& M. J. Sliwinski (Eds.), Handbooks of developmental psychology. 
The Wiley-Blackwell handbook of adulthood and aging (pp. 477-496). WileyBlackwell. https://doi.org/10.1002/9781118392966.ch24

Simonton, D. K. (2017). Creativity and free will: Creative thought enhances personal freedom? In M. Karwowski \& J. C. Kaufman (Eds.), The creative self: Effect of beliefs, self-efficacy, mindset, and identity (pp. 65-84). Academic Press.

Srivastava, S., John, O. P., Gosling, S. D., \& Potter, J. (2003). Development of personality in early and middle adulthood: Set like plaster or persistent change? Journal of Personality and Social Psychology, 84(5), 1041-1053. https://doi.org/10.1037/00223514.84.5.1041

Sternberg, R. J. (2002). Creativity as a decision. American Psychologist, 57(5), 376. https://doi.org/10.1037/0003-066X.57.5.376a

Sternberg, R. J. (2003). The development of creativity as a decision-making process. In Sawyer, R. Keith, V. John-Steiner, S. Moran, R. J. Sternberg, D. H. Feldman, J. Nakamura, \& M. Csikszentmihalyi (Eds.), Creativity and development (pp. 91-138). Oxford University Press.

Sternberg, R. J., \& Lubart, T. I. (1991). An investment theory of creativity and its development. Human Development, 34, 1-31. https://doi.org/10.1159/000277029

Sternberg, R. J., \& Lubart, T. I. (1995). Defying the crowd: Cultivating creativity in a culture of conformity. Free Press.

Terracciano, A., Costa, P. T. Jr., \& McCrae, R. R. (2006). Personality plasticity after age 30. Personality \& Social Psychology Bulletin, 32(8), 999-1009. https://doi.org/10.1177/0146167206288599

Tillier, W. (2018). Personality development through positive disintegration: The work of Kazimierz Dąbrowski. Bassett. 
Tomasco, S. (2018). IBM 2010 Global CEO Study: creativity selected as most crucial factor for future success. IBM. Retrieved from http://www03.ibm.com/press/us/en/pressrelease/31670. wss\# contact (accessed 08/10, 2020). Tsai, K. C. (2012). Play, imagination, and creativity: A brief literature review. Journal of Education and Learning, 1, 15-20. http://dx.doi.org/10.5539/jel.v1n2p15

Urban, K. K. (2005). Assessing creativity: The Test for Creative Thinking-Drawing Production (TCT-DP). International Education Journal, 6(2), 272-280.

von Stumm, S., Chung, A., \& Furnham, A. (2011). Creative ability, creative ideation and latent classes of creative achievement: What is the role of personality? Psychology of Aesthetics, Creativity, and the Arts, 5(2), 107-114. https://doi.org/10.1037/a0020499

Vygotsky, L. S. (1980). Mind in society: The development of higher psychological processes. Harvard University Press.

Vygotsky, L. S. (2004). Imagination and creativity in childhood, Journal of Russian \& East European Psychology, 42, 7-97. doi: 10.1080/10610405.2004.11059210.

Wright, C. A., \& Wright, S. D. (1987). The role of mentors in the career development of young professionals. Family Relations, 36(2), 204-208. DOI: 10.2307/583955

Wu, C. H., Cheng, Y., Ip, H. M., \& McBride-Chang, C. (2005). Age Differences in Creativity: Task Structure and Knowledge Base, Creativity Research Journal, 17(4), 321-326. https://doi.org/10.1207/s15326934crj1704_3

Wu, P. L. \& Chiou, W. B. (2008). Postformal thinking and creativity among late adolescents: A post-Piagetian approach. Adolescence, 43(170), 237-251

Zeng, L., Proctor, R. W., \& Salvendy, G. (2011). Can traditional divergent thinking tests be trusted in measuring and predicting real-world creativity? Creativity Research Journal, 23(1), 24-37. https://doi.org/10.1080/10400419.2011.545713 
Zhang, G., Li, H., \& Yan, S. (2020). The vital few: Exploring the role of expertise in the process of team creativity. Journal of Creative Behavior, advance online publication, https://doi.org/10.1002/jocb.466

Zhao, H., O'Connor, G., Wu, J., \& Lumpkin, G. T. (2020). Age and entrepreneurial career success: A review and a meta-analysis. Journal of Business Venturing, 106007. doi:10.1016/j.jbusvent.2020.106007

Zittoun, T., \& de Saint Laurent, C. (2015). Life-creativity: Imagining one's life. In V. P. Glaveanu, A. Gillespie, \& J. Valsiner (Eds.) Rethinking creativity: Contributions from cultural psychology. (pp. 58-75). Routledge. 